Vol.05, No.01, April 2019

Doi: $10.24198 /$ cosmogov.v2i2.xxxxx

\title{
SENGKARUT KEPENTINGAN AKTOR KEAMANAN (TINJAUAN ATAS DINAMIKA PERUMUSAN UU KEAMANAN NASIONAL)
}

\author{
Nanang Suryana \\ Magister Pascasarjana Ilmu Politik, FISIP, Universitas Padjadjaran \\ Email:nanangsuryana09@gmail.com
}

\begin{abstract}
ABSTRAK
Dinamika perumusan UU Kamnas dipengaruhi oleh banyak faktor. Salah satu faktor yang dominan adalah sengkarut kepentingan antar aktor keamanan, secara lebih spesifik, soal kewenangan pada masing-masing institusi. Selain berdimensi profesionalitas pembagian kewenangan, dinamika yang berkembang dipengaruhi juga oleh politik ingatan. Keberadaan Dewan Keamanan Nasional (DKN) dikhawatirkan akan mereplikasi keberadaan Komando Pemulihan Keamanan dan ${ }^{1}$ Ketertiban (Kopkamtib) atau Badan Koordinasi Bantuan Pemantapan Stabilitas Nasional (Bakorstanas) era orde baru. Dinamika perumusan UU Kamnas secara faktual memperlihatkan dengan nyata, isu keamanan nasional dewasa ini juga melibatkan banyak aktor di luar negara (non-state actors). Dalam konteks perumusan kebijakan, UU Kamnas harus dirumuskan dalam kerangka democratif governance dengan berpangkal pada: control publik dan kesetraan sebagai aktor kebijakan.
\end{abstract}

Kata Kunci: UU keamanan nasional; aktor keamanan; democratic governance.

\begin{abstract}
The dynamics of formulation National Security Law is influenced by many factors. One dominant factor is the conflict of interests between security actors, more specifically, about the authority of each institution. In addition to the dimensions of professionalism in the division of authority, the dynamics that develop are also influenced by memory politics. The existence of the National Security Council $(D K N)$ is feared to replicate the existence of the Command for the Restoration of Security and Order (Kopkamtib) or National Stability Stabilization Assistance Agency (Bakorstanas) at new order area. The dynamics of formulation the National Security Law factually shows clearly, the issue of national security today also involves many actors outside the country (non-state actors). In the context of policy formulation, the National Security Law must be formulated in the framework of democratizing governance by starting with: public control and equality as a policy actor.
\end{abstract}

Keywords: national security act; security actor; democratic governance. 
Vol.05, No.01, April 2019

Doi: $10.24198 / \operatorname{cosmogov.v2i2.xxxxx}$

\section{PENDAHULUAN}

Kebijakan lahir guna merespon kebutuhan. Sebagai produsen kebijakan, perspektif negara dalam memandang permasalahan, akan sangat menentukan kebijakan mana yang akan didahulukan untuk dilahirkan. Dalam perspektif ini, kebijakan dapat dilihat sebagai titik silang pertemuan antara respon atas kebutuhan penyelesaian persoalan, dan pengakomodiran kepentingan kekuasaan.

Sebagaimana yang dipahami secara luas, sebuah kebijakan tidak lahir dari ruang kosong. Kebijakan adalah abstraksi dari lalu lintas antar kepentingan, yang seringkali bersembunyi di banyak dalil-dalil publik. Seolah menjadi jawaban atas kebutuhan umum, sebuah isu berkembang menjadi menu utama di atas meja perumusan dengan tawaran menu-menu lain yang banyak berisisan.

Di antara banyak isu yang masih menyita perhatian publik, isu perumusan undang-undang kemananan nasional, menjadi salah satu isu yang masih bertengger di kelasemen atas diskurusus publik. Selain karena durasi waktu perdebatan yang tak kunjung menemui titik sepakat, soal tentang kepentingan masing-masing aktor keamanan yang tak berkesudahan, menjadi isu lain yang menarik untuk ditelisik.
Gagasan penyusunan rancangan UU Kamnas dilatari oleh keinsyafan banyak pihak tentang perkembangan pola ancaman yang berdampak pada keharusan untuk merubah paradigma kemananan nasional yang selama ini dianut. Perubahan lingungan strategis yang terus berkembang, berdampak pada pergeseran paradigma kemananan. Potensi ancaman yang multidimensional, menghendaki respon positif secara politik hukum dari negara. Dalam kerangka tersebut, perdebatan tentang Undang-Undang Keamanan Nasional mengemuka.

\section{Rumusan Masalah}

Berdasar latar belakang di atas, tulisan ini berupaya untuk melihat dinamika perumusan kebijakan UU Kamnas, dalam perspektif kepentingan aktor keamanan. Secara sistematis, tulisan ini akan mengelobarasi perdebatan yang berkembang, dan mencoba untuk mencari simpul pertemuan antar isu. Sehingga, diharapkan dapat terpetakan sengkarut kepentingan dalam dinamika perumusan UU Kamnas.

\section{HASIL DAN PEMBAHASAN}

\section{Tinjauan Konseptual}

Konsep keamanan telah berkembang seiring dengan laju perkembangan dan dinamika zaman. Secara etimologis, keamanan (security) berasal dari bahasa latin "securus" (se+cura) yang bermakna terbebas dari bahaya, terbebas dari 
Vol.05, No.01, April 2019

Doi: $10.24198 /$ cosmogov.v2i2.xxxxx

ketakutan. Kata ini juga bisa bermakna dari gabungan kata se (yang berarti tanpa/without) dan curus (yang berarti "uneasiness"). Sehingga bila digabungkan kata ini bermakna "liberation from uneasinness, or a peaceful situation without any risks or threats". (Anak Agung Banyu Perwita, 2006 dalam Al, Araf 2015)

Di awal perkembangannya, isu kemananan berpusat pada negara. Isu keamanan hanya dipahami dalam perspektif ancaman militer antar negara. Namun, seiring perkembangan demokratisasi, khsusunya gelombang isu hak asasi manusia dan terjadinya fenomena terorisme, paradigma keamanan tidak lagi berpusat pada negara dengan ancaman limiter, namun juga aktor diluar negara dengan ancaman nirmiliter.

Barry Buzan mendefinisikan lima sektor utama yang dicakup dalam pengertian keamanan yakni: (1) the military security yang mencakup dua tingkat pengelolaan kapabilitas persenjataan negara baik secara ofensif maupun defensif dan persepsi negara terhadap intensitas satu dengan yang lainnya; (2) the political security yang menaruh perhatian pada stabilitas organisasi negara, sistem ideologi dan ideologi yang memberi legitimasi kepada pemerintahan; (3) the economic security yang mencakup pada akses terhadap sumberdaya, keuangan dan pasar yang untuk menopang tingkat kesejahteraan dan kekuatan negara yang akseptabel; (4) societal security yang mencakup kelangsungan pola tradisi dari bahasa, budaya, agama, identitas nasional dan adat termasuk di dalamnya kondisi evolusi yang bisa diterima; dan (5) environmental security yang menaruh perhatian pada pemeliharaan lingkungan baik secara lokal maupun global sebagai sebuah dukungan penting terhadap sistem tempat kehidupan manusia bergantung. Dan masing-masing sektor tidak berdiri sendiri melainkan memiliki ikatan kuat satu sama lain. (Buzan, 1991 dalam Al, Araf 2015)

Perkembangan lain dalam isu kemanan adalah lahirnya konsep yang dikenal dengan human security. Secara konseptual, human security, sebagaimana ditulis oleh Roland Paris meliputi 7 (tujuh) komponen utama yaitu 1) keamanan ekonomi, 2) keamanan pangan, 3) keamanan kesehatan, 4) keamanan lingkungan hidup, 5) keamanan personal (keamanan fisik seperti kekerasan, kecelakaan, dll), 6) keamanan sosial budaya, dan 7) keamanan politik (Roland Paris, 2001: 89). Hampir senada, Jorge Nef mengklasifikasikan human security kedalam 5 kelompok yakni 1) keamanan lingkungan hidup, personal dan fisik, 2) keamanan ekonomi, 3) keamanan sosial, 4) keamanan politik, dan 5) keamanan budaya (Jorge Nef, 1997: 25 dalam Sanak, 2012).

Dalam konteks perumusan kebijakan, RUU Kamnas sejatinya dirumuskan dalam kerangak 
Vol.05, No.01, April 2019

Doi: $10.24198 /$ cosmogov.v2i2.xxxxx

democratic governance. Makna demokratis di sini adalah demokrasi yang berkualitas, yang dapat dilihat dari: (a) hasil (quality of result), yang dirasakan manfaatnya secara langsung oleh masyarakat; (b) Isi (quality of contents), diarahkan bagi kepentingan masyarakat; (c) prosedur (procedural quality), yang proses perumusannya melibatkan partisipasi masyarakat. (Eko Prasojo, 2010 dalam Titiswasanan, 2013).

Terdapat dua prinsip dasar dari norma demokrasi dimaksud yaitu: (a) Berjalannya kontrol masyarakat terhadap kebijakan publik dan pembuat kebijakan; (b) Kesetaraan antar masyarakat dalam relasinya dengan proses perumusan kebijakan publik. Pemahaman ini mencerminkan dinamika pada tata pemerintahan, yang membawa perubahan paradigma pemerintahan kepada paradigma tata pemerintahan yang baik dan demokratis (democratic governance).

\section{Dinamika Perdebatan}

Pusaran perdebatan dalam dinamika perumusan RUU Kamnas salah satunya terkait dengan sengkarut kepentingan antar aktor keamanan. Selain POLRI, TNI, dan BIN, sebagai institusi negara yang mengurusi soal keamanan, seiring dengan perkembangan demokratisasi, keterlibatan civil society yang direpresentasikan oleh NGO yag berfokus pada isu ini juga menjadi bagian yang tidak terpisahkan.
Terlebih, dengan konsep human security, keamanan dilihat sebagai sebuah fenomenan multidimensi.

Pusat perdebatan yang berkisar pada soal kewenangan aktor kemananan, mengerucut pada soal propsorsionalitas kelembangaan. Dari kacamata POLRI setidaknya ada sepuluh potensi kewenangan Polri yang akan tereduksi dalam RUU Kamnas, yakni: Penyusunan kebijakan dan pengajuan anggaran; Posisi Polri di bawah kementerian; Pemberantasan terorisme; Penanganan konflik sosial; penangan pengacau keamanan; Pembinaan keamanan lingkungan; Posisi Polri di Forum Muspida; Posisi Polri di Kominda; Akses Bantuan Hibah dan Kerja sama Pemda; Akses politik dan ekonomi.

Posisi POLRI dalam konteks UU Kamnas memang dilematis. Pasca berpisah dengan TNI dalam tubuh ABRI, POLRI relatif memiliki banyak insentif, selain kedudukannya yang langsung dibawah presiden, bahkan dalam kontek penganggaran POLRI dapat mengajukan langsung kepada DPR. Beda halnya dengan TNI yang berada dibawah otoritas sipil Kementrian Pertahannan. Hal ini yang selama ini cukup menyita perhatian banyak kalangan terkait dengan relasi antar isntitusi keamanan. (Muradi,)

Dalam kondisi ini, disatu sisi POLRI ingin tetap dipercaya publik sebagai instutusi yang mendukung 
Vol.05, No.01, April 2019

Doi: $10.24198 / \operatorname{cosmogov.v2i2.xxxxx}$

pemajuan demokrasi dengan mendukung gagasan pengaturan sektor keamanan dalam UU Kamnas. Namun, disisi lain, POLRI merasa harus berhati-hati untuk tidak terjebak dalam perangkap relasi kelembagaan. Jika tidak, POLRI akan kehiilangan keutungan yang selama ini mereka miliki.

Lain halnya dari kacamata non-governmental organizations (NGO), RUU Kamnas ditakutkan akan memberi ruang potensi untuk kembali ke zaman orde baru, dengan kehadiran Dewan Keamanan Nasional (DKN) yang dikhawatirkan akan mereplikasi peran dari Komando Pemulihan Keamanan dan Ketertiban (Kopkamtib) atau Badan Koordinasi Bantuan Pemantapan Stabilitas Nasional (Bakorstanas).

\begin{tabular}{lrr}
\multicolumn{2}{c}{ Kekhwatiran ini } & dapat \\
dipahami mengingat & sejarah \\
pegaturan sektor kemananan pada era \\
orde $\quad$ baru
\end{tabular}
mencampuradukannya dengan sektor pertahahanan. Keamanan yang bersifat multidimensi tidak hanya bersifat menjaga batas-batas teritorial negara (keadulatan nasional), tetapi juga harus menjamin keamanan dan melindungi warga negara (manusia). kondisi yang menempatkan aparat militer diluar pertahanan hanya akan menyebabkan distorsi terhadap tatanan demokrasi. Sejarah Indonesia telah membuktikan bagaimana kehidupan demokrasi dan civil society mengalami kelumpuhan sepanjang pemerintahan Orde Baru akibat penyatuan dimensi pertahanan dan keamanan dijadikan satu. (Al, Araf, 2015)

Namun, seiring dengan perkembangan ancaman dalam konteks keamanan, seperti munculnya aksi terorisme, tentu juga harus menjadi perhatin. Peribatan TNI dalam konteks ini sejatinya dapat menjadi pertimbangan, menginkat skala ancaman dan beban tugas yang diemban. Hal ini menjadi penting guna menjaga efektivitas beban tugas.

Sehingga dapat dipahami, TNI melihat dinamika ancaman nasional dewasa ini harus direspon melaui sebuah pembaharuan tata kelola sektor keamanan yang juga multidimensional. Keamanan dalam negeri dalam perspektif ini, tidak dipahami hanya menjadi domain polisi, terlebih setelah perkembangan ancaman seperti terorisme, menghendaki adanaya keterlibatana aktor keamanan lain secar lebih proporsional.

Namun, ditengah perdebatan tentang kewenangan soal relasi antar aktor keamanan ini, yang juga harus menjadi perhatian adalah soal proses permusan kebijakan UU Kamnas dapat dipahami dalam kerangka democratic governance, dimana publik dilibatkan secara proporsional, dan posisi yang setara antara masingmasing institusi dan aktor keamanan. 
Vol.05, No.01, April 2019

Doi: $10.24198 / \operatorname{cosmogov.v2i2.xxxxx}$

\section{KESIMPULAN}

Faktor kepentingan masingmasing aktor keamanan, menjadi salah faktor yang mendominasi perdebatan dalam dinamika permusan UU Kamnas. Dengan berbekal masing-masing agenda, proses perumusan UU Kamnas harus tetap berpijak pada prinsip democratic governance: perlibatan dan kesetaraan.

Dengan perkembangan ancaman dewasa ini, masing-masing aktor keamanan harus mampu melihat relasi kewenangan antara isntusi ini sebagai bagian dari pencapaian tujuan dan kepentingan negara. Bukan semata-semata, demi melindungi kepentingan lembaganya saja. Jika itu yang terjadi, UU Kamnas akan berlarut-larut dan Indonesia tidak akan melangkah juga dan memiliki perkembangan yang berarti dalam konteks tata kelola sektor keamanan.

\section{DAFTAR PUSTAKA}

\section{Buku}

Al A'raf. (2015). Dinamika Keamanan Nasional, Jurnal Keamanan Nasional Vol. I No. 12015

Muradi, RUU Keamanan Nasional dan Sikap Polri, dalam http://pustaka.unpad.ac.id/wpco ntent/uploads/2013/08/pustaka unpad RUU Keamanan Nasion al dan Sikap Polri.pdf (Diakses 15 Mei 2018)
Yohanes Sanak, Penguatan Human Security sebagai Strategi Pengelolaan Perbatasan Indonesia-Malaysia, Jurnal Ilmu Sosial dan Ilmu Politik, Volume 16, Nomor 2, November 2012 (125-135), ISSN 1410-4946

Winantuningtyas Titiswasanan. (2013). Democratic Governance dalam Perumusan Kebijakan Publik. (Sumber PDF. Diakses 5 Mei 2018) 